\title{
PENGARUH PENGEMBANGAN KARIR DAN MANAJEMEN KONFLIK TERHADAP KINERJA BPJS KESEHATAN CABANG PALU
}

\author{
RATKLIF VEBRIANTO TUMPAI \\ NILUH PUTU EVY ROSSANTY \\ Program Studi Manajemen, Fakultas Ekonomi dan Bisnis, Universitas Tadulako \\ Email: yerikoratklif@gmail.com; npe.rossanty@gmail.com
}

\begin{abstract}
This study aims to study and analyze: (1) Career Development and Conflict Management that supports the performance of employees at BPJS Branch Palu. (2) Career Development of Public Support for the Performance of BPJS Health Employee Branch Palu. (3) Conflict Management on the Performance of Employees of BPJS Health, Branch Palu. This study uses quantitative research which is a study that aims to explain the relationship between variables or more with a sample of 36 employees and the data analysis technique used is multiple linear regression. The results of the analysis and the hypothesis testing can be concluded that: (1) Based on the results of the regression test obtained sig. $F$ is $0,00<0,005$, which can be interpreted as avariable in Career Development and Conflict Management in unison responsibilities towards Employee Performance. (2) Based on the results of the regression test obtained the careerDevelopment variable has a significance level $t$ sig. 0,000 $<_{a} 0,005$, which can be interpreted as a variable Career Development partially significant influence on Employee Performance. (3) Based on the results of the regression test obtained the Conflict Management variable has a significance level t sig. 0,000 $<_{a} 0,005$ which can be interpreted as a partial Conflict Management variable that has a significant effect on employee performance.
\end{abstract}

Keywords: Career Development, Conflict Management, Employe Performance.

\begin{abstract}
Abstrak
Penelitian ini bertujuan untuk mengetahui dan menganalisis: (1) Pengembangan Karir dan Manajemen Konflik berpengaruh serempak terhadap Kinerja Pegawai pada BPJS Kesehatan Cabang Palu. (2) Pengembangan Karir berpengaruh secara parsial terhadap Kinerja Pegawai BPJS Kesehatan Cabang Palu. (3) Manajemen Konflik berpengaruh secara parsial terhadap Kinerja Pegawai BPJS Kesehatan Cabang Palu. Penelitian ini menggunakan penelitian kuantitatif yang merupakan penelitian yang bertujuan untuk menjelaskan hubungan antara dua variabel atau lebih dengan sampel 36 pegawai dan teknik analisis data yang digunakan adalah regresi linear berganda. Hasil analisis dan pengujian hipotesis dapat disimpulkan bahwa: (1) Berdasarkan hasil uji regresi diperoleh sig. F sebesar $0,00<0,05$, yang dapat diartikan bahwa variabel Pengembangan Karir dan Manajemen Konflik berpengaruh secara serempak terhadap Kinerja Pegawai. (2) Berdasarkan hasil uji regresi diperoleh variabel Pengembangan Karir memiliki tingkat signifikansi t sig. $0,000<\alpha 0,05$, yang dapat diartikan bahwa variabel Pengembangan Karir secara parsial berpengaruh signifikan terhadap Kinerja Pegawai. (3) Berdasarkan hasil uji regresi diperoleh variabel Manajemen Konflik memiliki tingkat signifikansi t sig. $0,000<\alpha 0,05$ yang dapat diartikan bahwa variabel Manajemen Konflik secara parsial berpengaruh signifikan terhadap Kinerja Pegawai.
\end{abstract}

Kata kunci: Pengembangan Karir, Manajemen Konflik, Kinerja Pegawai.

\section{PENDAHULUAN}

Pegawai adalah faktor penting dalam perencanaan serta pelaku aktif dalam setiap kegiatan organisasi. Pegawai bertugas dalam menjalankan alat-alat kantor, menjalankan tanggung jawab sesuai dengan job description (Wright dan Snell dalam Hendy, 2016). 
Peranan pegawai atau sumber daya manusia sangat menentukan keberhasilan dalam organisasi. Hal ini mengingat bahwa potensi yang ada pada sumber daya manusia berperan sangat besar pada organisasi dalam mencapai tujuannya. Maka dari itu diharapkan organisasi dapat menyadari serta membuat suatu sistem yang mengelolah dan melihat dengan cermat hal-hal yang dapat berpengaruh pada menyikapi pekerjaan para pegawai agar terwujudnya hal yang menjadi tujuan dari organisasi. Agar mendapat hal tersebut, sebuah organiasis berharap kinerja yang tinggi dari para pegawainya.

Kinerja adalah hal yang diperoleh dalam nilai dan hasil yang baik diperoleh kariawan pada saat bekerja (Mangkunegara, 2001:67). Kinerja adalah kelakuan yang real dinyatakan dalam setiap prestasi pekerjaan berdasarkan kegiatannya di dalam perusahaan, Rivai 2004.

Berdasarkan hasil wawancara dengan salah satu staf BID. SDM \& KOMUNIKASI INTERNAL (Vosta Claudia) pada tanggal 7 Juni 2018 mengatakan bahwa kinerja pegawai BPJS Kesehatan Cabang yang berada di Jl. Sisingamangaraja No.31 Palu, belum sepenuhnya maksimal. Dalam hal ini sering terjadi keterlambatan dalam proses pelayanan dan pengurusan berkas oleh pegawai yang bersangkutan, sehingga mempengaruhi kualitas pekerjaan. Maka tidak jarang hal ini sering menjadi keluhan dari para nasabah.

Jika dilihat dari fungsi dari BPJS itu sendiri adalah memberikan pelayanan terbaik bagi masyarakat dalam proses penyelenggaraannya, namun pada kenyataan yang ada bertolak belakang dengan fenomena yang terjadi di lapangan. Selanjutnya dalam kehadiran pun masih terdapat beberapa pegawai yang sering datang terlambat, sehingga hal ini mempengaruhi hasil pekerjaan yang tadinya bisa diselesaikan jika datang tepat waktu, namun tertunda akibat sering datang terlambat.

Pegawai adalah perangkat yang penting didalam setiap organisasi baik pada pencapaian tujuan kantor maupun instansi secara efektif (Sartika, 2015). Keberadaan pengembangan karir diperlukan oleh setiap pegawai untuk dapat meningkatkan kinerja yang optimal, yang mana persepsi mereka terhadap pengembangan karirnya akan membawa konsekuensi terhadap hasil kinerja yang diberikan untuk organisasi. Pegawai yang mempersepsi pengembangan karirnya secara positif cenderung akan memotivasinya untuk memberikan hasil kinerja yang lebih baik.

Pengembangan karir merupakan kegiatan pegawai yang ingin berkarya pada organisasi dalam bekerja untuk waktu cukup lama sampai pensiun. Siagian (2011). Pengembangan karir bisa dikatakan proses menumbuhkan kemampuan kerja individu yang dicapai dalam rangka meniti karir yang diinginkan, Rivai dan Sagala (2009).

Berdasarkan hasil wawancara dengan salah satu staf SDM \& KOMUNIKASI INTERNAL (Vosta Claudia) pada tanggal 7 Juni 2018, mengatakan bahwa penilaian kinerja yang dilakukan oleh atasan belum sepenuhnya mendapat perlakuan yang adil. Dalam kejadiannya dinilai berkinerja baik tetapi di balik itu adanya kekeliruan yakni, ada beberapa pekerjaan yang tidak diselesaikan tetapi mereka dianggap melakukan kinerja dengan baik. Selanjutnya pengembangan karir pegawai juga belum sepenuhnya mendapatkan promosi yang sesuai dengan prosedur, yakni ada pegawai yang karirnya cepat meningkat, bahkan ada juga pegawai yang telah bekerja cukup lama namun belum berkesempatan untuk mengembangkan karirnya.

Selain dari pengembangan karir, manajemen konflik juga sangat berpengaruh terhadap kinerja pegawai. Yaitu jika seorang pimpinanan organisasi mampu memanaj konflik di dalam perusahaan atau organisasi tersebut maka proses kinerja pegawai akan terkontrol dan akan tetap berada pada jalur sistem organisasi yang berlaku pada perusahaan tersebut.

Konflik biasannya nampak pada organisasi yang merupakan hasil timbulnya masalah hubungan pribadi, komunikasi, dan struktur organisasi. Penyebab suatu konflik berasal dari hubungan komunikasi, struktur dan pribadi.

Dilihat dari manfaatnya, ada konflik yang bersifat fungsional dan disfungsional. Konflik fungsional adalah konflik yang mendukung tercapainya tujuan dan meningkatkan kinerja kelompok. 
Sementara konflik disfungsional adalah konflik yang menghambat kinerja kelompok (Marwansyah 2016:305).

Manajemen konflik merupakan cara yang digunakan pimpinan saat menanggapi konflik (Hardjaka 1994) dalam Wahyudi (2015:47). Sementara (Tosi, H. L. et al. 1990) dalam Wahyudi, (2015:47), mengatakan yaitu manajemen konflik pada organisasi merupakan pertanggungan jawab manajer lini, tengah, dan atas maka dari iru sangat perlu berperan akrif dalam mengarahkan konflik. Selanjutnya menurut Wirawan 2010:131, Manajemen konflik merupakan strategi dalam mengolah perusahaan dan pribadi untuk mengidentifikasi dan mengelolah keanekaragaman supaya beban dan pengeluaran konflik terkelolah, menggunakan situasi konflik suapaya menjadi inovasi dan mempermantap. Dengan adanya pengaturan konflik baik dari manajer perusahaan, diharapkan akan dapat meminimalisir konflik dari pihak perusahaan atau organisasi, maupun pegawainya.

Hasil wawancara dengan seorang pegawai (Sahabudin dan Dian Meyta) pada tanggal 8 Juni 2018, mengatakan bahwa manajemen konflik pada BPJS Kesehatan Cabang Sisingamangaraja No.31 Palu, belum sepenuhnya maksimal. Dalam hal ini pengakomodasian oleh pimpinan juga masih kurang dan dapat dilihat dari beberapa kejadian konflik antar pegawai namun tidak diketahui oleh pimpinan, sehingga pimpinan terlambat mengambil keputusan dan akibatnya masalah atau konflik yang timbul akan berlarut-larut dan memicu untuk timbulnya konflik yang lebih besar lagi. Hal inilah yang juga akan mempengaruhi proses dan hasil kinerja, dan imbasnya akan terasa bagi perusahaan.

Selanjutnya tentang kompetisi, dalam hal ini masih ada beberapa pegawai yang tidak melakukan kompetisi secara adil dengan rekan kerja. Dapat dilihat dari beberapa kejadian yaitu beberapa pegawai memenangkan persaingan dengan melakukan hal-hal yang tidak sesuai dengan peraturan dan menjatuhkan lawan konflik dan mendapat tanggapan positif dari atasan dikarenakan atasan tidak mengetahui permasalahan yang sesungguhnya.

\section{KAJIAN LITERATUR DAN PENGEMBANGAN HIPOTESIS}

Hasibuan (2009:69), pengembangan karir merupakan suatu usaha dalam memaksimalkan keahlian teknis, teoritis, konseptual, dan moral para pegawai berdasarkan kebutuhan para pekerja dengan diklat.

Pengembangan karir merupakan kegiatan pegawai yang ingin berkarya pada organisasi dalam bekerja untuk waktu cukup lama sampai pensiun. Siagian (2013:316).

Menurut Mangkunegara (2001:77), Pengembangan karir yaitu kegiatan pegawai yang mengantarkan para pegawai menyususn karir untuk kehidupan yang akan datang di perusahaan sehingga perusahaan serta pegawai yang bersangkutan dapat mengembangkan kemampuan secara maksimal.

Pengembangan karir bisa dikatakan proses menumbuhkan kemampuan kerja individu yang dicapai dalam rangka meniti karir yang diinginkan, Rivai dan Sagala (2009:281).

Berdasarkan beberapa pendapat para ahli di atas maka dapat disimpulkan bahwa pengembangan karir merupakan segala sesuatu yang berkaitan dengan kedudukan seseorang di masa sekarang dan di masa yang akan datang dalam rangka meningkatkan kualitas dan kuantitas seorang pegawai.

Cribin, J. (1982:219) dalam Wahyudi, 2015:47, mengatakan manajemen konflik adalah teknik yang dilakukan pimpinan organisasi sehingga dapat mengatur konflik dengan cara menentukan peraturan dasar didalam persaingan.

Manajemen konflik merupakan cara yang digunakan pimpinan saat menanggapi konflik (Hardjaka 1994) dalam Wahyudi (2015:47).

Wirawan 2010:131, Manajemen konflik merupakan strategi dalam mengolah perusahaan dan pribadi untuk mengidentifikasi dan mengelolah keanekaragaman supaya beban dan pengeluaran konflik terkelolah, menggunakan situasi konflik suapaya menjadi inovasi dan mempermantap. 
Hendricks W., 1992, dalam Wahyudi, 2015:47, manajemen konflik yaitu cara yang digunakan pemimpin saat menaksir serta memperhitungkan konflik.

Berdasarkan pendapat dari beberapa para ahli di atas maka dapat disimpulkan bahwa manajemen konflik merupakan sebuah sikap yang digunakan dalam menangani dan mengelolah konflik sehingga keamanan dan kenyamanan pada organisasi tetap terjaga.

Kinerja adalah hasil pekerjaan yang dicapai pegawai berdasarkan persyaratan-persyaratan pekerjaan. Bangun, (2012:231).

Kinerja adalah hal yang diperoleh dalam nilai dan hasil yang baik diperoleh kariawan pada saat bekerja (Mangkunegara, 2001:67).

Menurut Dessler (2000:94) kinerja merupakan catatan terhadap hasil produksi dari sebuah pekerjaan tertentu atau aktivitas tertentu.

Mangkunegara (2005:75) menyatakan bahwa pada umumnya kinerja dibedakan menjadi dua, yaitu kinerja individu dan kinerja organisasi. Kinerja individu adalah hasil kerja pegawai baik dari segi kualitas maupun kuantitas berdasarkan standar kerja yang telah ditentukan, sedangkan kinerja organisasi adalah gabungan dari kinerja individu dan kinerja kelompok.

Dari beberapa pendapat para ahli di atas maka dapat disimpulkan kinerja adalah segala sesuatu tindakan yang akan memberikan sebuah hasil yang positif dan negatif dalam penyelesaian tujuan organisasi.

Pengembangan karir dan manajemen konflik dapat memberikan pengaruh terhadap kinerja pegawai. Pengembangan Karir merupkan hal yang tidak bisa dipisahkan dari pegawai karena melalui pengembangan karir, pegawai akan terpacu dan semakin giat dalam proses pelaksanaan kinerjanya didalam perusahaan.

Pengelolahan manajemen konflik yang baik oleh pimpinan di dalam perusahaan, akan menciptakan suasana dan lingkungan kerja yang baik, dan tidak menutup kemungkinan hasil kinerja pegawai pun akan semakin membaik.

Peranan pegawai atau sumber daya manusia sangat menentukan keberhasilan dalam organisasi. Hal ini mengingat bahwa potensi yang ada pada sumber daya manusia berperan sangat besar pada organisasi dalam mencapai tujuannya. Maka dari itu diharapkan organisasi dapat menyadari serta membuat suatu sistem yang mengelolah dan melihat dengan cermat hal-hal yang dapat berpengaruh pada menyikapi pekerjaan para pegawai agar terwujudnya hal yang menjadi tujuan dari organisasi. Agar mendapat hal tersebut, sebuah organiasis berharap kinerja yang tinggi dari para pegawainya.

Pegawai adalah faktor penting dalam perencanaan serta pelaku aktif dalam setiap kegiatan organisasi. Pegawai bertugas dalam menjalankan alat-alat kantor, menjalankan tanggung jawab sesuai dengan job description (Wright dan Snell dalam Hendy, 2016).

Observasi yang dilakukan pada BPJS Kesehatan Cabang Palu yaitu terdapat fenomena yang perlu diteliti dan perlu didalami lagi. Fenomena tersebut adalah pengembangan karir dan manajemen konflik terhadap kinerja pegawai pada BPJS Kesehatan Cabang Palu yang belum maksimal. Berdasarkan uraian di atas maka dapat dikembangkan ke dalam kerangka pemikiran.

\section{Hubungan Pengembangan Karir dan Kinerja Pegawai}

Caroline \& Susan (2014) mengatakan bahwa seorang pemimpin yang mengharapkan pencapaian kinerja yang baik pada organisasinya harus memperhatikan faktor-faktor yang mempengaruhi kinerja pegawainya itu sendiri, salah satunya adalah pengembangan karir (career development). Dari hal ini maka dapat diambil kesimpulan bahwa untuk meningkatkan kinerja pegawai, salah satu tunjangan yang harus dilaksanakan adalah dengan mengembangkan karir pegawai.

\section{Hubungan Manajemen Konflik dan Kinerja Pegawai}

Manajemen konflik merupakan salah satu penentu kesuksesan dari sebuah pekerjaan. Ketika terjadi konflik, maka secara otomatis proses kinerja yang berlangsung pada organisasi akan terganggu. Maka 
dari itu pengelolahan konflik yang benar sangat dibutuhkan dalam organisasi untuk dapat memberikan rasa nyaman dan aman bagi para pegawai dalam melaksananakan kinerjanya.

Upaya ini akan memberikan pengaruh positif bagi psikis individu dan kelompok kerja karena adanya perasaan kerlibatan dan penghargaan atas kemampuan, keahlian yang dimiliki menjadi bermanfaat untuk mencapai tujuan yang diharapkan perusahaan/lembaga sehingga sudah tentu hasil upaya tersebut akan berdampak dalam meningkatkan kinerja, baik kinerja individu maupun kelompok kerja.

\section{Hubungan Pengembangan Karir dan Manajemen Konflik dengan kinerja Pegawai}

Berdasarkan hasil penelitian yang dilakukan oleh Mawarni, dkk 2012) menunjukkan bahwa Iklim Organisasi dan Pengembangan Karir secara bersama-sama terdapat pengaruh yang sinifikan terhadap meningkatnya kinerja Pegawai pada Dinas Sosial Aceh. Hal ini berarti adanya Pengembangan Karir bagi Pegawai maka Kinerja Pegawai akan meningkat secara signifikan.

Hasil penelitian Rozzalina (2013) menunjukkan secara bersamaan Gaya Kepemimpinan dan Manajemen Konflik memberikan pengaruh terhadap Kinerja Karyawan PT. Sinar Sosro Kantor Wilayah Penjualan (KPW) Jawa Timur. Hal ini menunjukkan bahwa dengan adanya Manajemen Konflik yang baik oleh Pimpinan maka akan meningkatkan Kinerja Karyawan.

\section{METODE PENELITIAN}

Penelitian ini menggunakan jenis penelitian dengan metode asosiatif dan hubungan kasual, karena tujuan penelitian ini adalah untuk menjelaskan hubungan sebab akibat pada bentuk pengaruh antar variabel melalui pengujian hipotesis. Dalam Sugiyono (2014:55) penelitian asosiatif adalah suatu pertanyaan penelitian yang bersifat menanyakan hubungan pada kedua variabel atau lebih. Dari variabel tersebut, selanjutnya dicari berapa besar pengaruh variabel independen pengembangan karir, dan manajemen konflik terhadap variabel dependen kinerja pegawai BPJS Kesehatan Cabang Palu.

Lokasi penelitian adalah tempat melakukan penelitian guna memeperoleh data penelitian. Penelitian ini dilaksanakan pada BPJS Kesehatan Cabang Palu. Adapun alasan penulis memilih lokasi tersebut karena berdasarkan observasi awal bahwa masih terdapat permasalahan yang berkaitan dengan variabel pengembangan karir dan manajemen konflik terhadap kinerja pegawai.

Sugiyono 2010:137, Bentuk data yang akan digunakan pada penelitian yaitu bentuk primer dan sekunder. Data primer merupakan data didapat dengan langsung dalam subjek penelitian, contoh angket, wawancara, dan sebagainya. Sebaliknya sekunder merupakan data tidak seketika terdapat data dalam pengumpulan data. Maka dalam penelitian ini sumber data primer dan sekunder yaitu:

\section{Data primer.}

Adalah data yang berdasarkan wawancara, dan melalui observasi dan data melalui kuisioner disebarkan pada sejumlah responden yang sesuai dengan target penelitian serta dianggap mewakili seluruh populasi data penelitian.

2. Data sekunder.

Merupakan artikel yang disesuaikan juga situasi informasi IT yang baik dilakukan dalam penelitian.

1. Uji Asumsi Klasik

Masalah-masalah yang ada dalam pengujian model regresi pada penelitian ini dapat diatasi dengan menggunakan bentuk model pengujian klasik terhadap kenormalan hasil persamaan regresi tersebut dapat dijabarkan sebagai berikut.

a. Uji Normalitas agar dapat mengetahui data yang digunakan berdistribusi normal atau tidak. Uji ini dilakukan dengan melihat histogram atas nilai residual dan grafik nornal probabilitas plot. Deteksi dengan melihat penyebaran data (titik) pada sumbu diagonal dari grafik. Dasar pengambilan 
keputusan, jika data penyebaran disekitar garis diagonal maka model regresi memenuhi asumsi normalitas dan jika data yang menyebar jauh dari arah diagonal dan tidak mengikuti arah garis diagonal maka model regresi tidak memenuhi asumsi normalitas.

b. Uji heteroskedastisitas bertujuan menguji apakah dalam model regresi terjadi ketidaksamaan varian dan residual suatu pengamatan yang lain tetap, maka homokedastisitas dan bila berbeda disebut heteroskedastisitas. Model regresi yang baik adalah homokedastisitas atau tidak terdapat heteroskedastisitas.

c. Uji multikolinearitas digunakan untuk menguji apakah dalam model regresi terdapat korelasi antar variabel bebas (variabel independen), yang dimana model regresi yang baik dan benar seharusnya tidak memiliki korelasi antar variabel independennya. Multikolinearitas dilakukan dengan cara menyocokkan nilai tolerence dan variance inflation factor (VIF) yaitu 10, yang dimana apabila nilai tolerence lebih kecil dari 0.10 dan nilai VIF lebih besar dari 10, maka terjadi multikolinearitas.

2. Analisis Deskriptif

Analisis deskriptif adalah statistik yang digunakan untuk menganalisa data dengan cara mendeskripsikan atau menggambarkan data yang telah terkumpul sebagaimana adanya tanpa bermaksud membuat kesimpulan yang berlaku untuk umum atau generalisasi, Sugiyono (2014:206).

3. Analisis Regresi Linear Berganda

Analisis ini digunakan untuk mengetahui seberapa besar pengaruh variabel bebas yaitu pengembangan karir (X1), dan manajemen konflik (X2) terhadap variabel terikatnya yaitu kinerja pegawai (Y). Metode analisis data yang digunakan dalam penelitian ini adalah menggunakan model regresi linear berganda (multipleregression). Alat analisis parametrik regresi linear berganda memiliki bentuk persamaan menurut Rangkuti (2006:165) dapat digambarkan sebagai berikud:

$$
Y=a+b^{1} X^{1}+b^{2} X^{2}+\cdots+b n X n+e
$$

Apabila formulasi matematis Regresi Linear Berganda diaplikasikan dalam penelitian ini, dapat diperoleh bentuk persamaan sebagai berikud:

$$
Y=a+b_{1} X_{1}+b_{2} X_{2}+e
$$

Dimana:

$$
\mathrm{Y} \quad=\text { Kinerja Pegawai }
$$

a $=$ Konstanta

$\mathrm{b}_{1}-\mathrm{b}_{2} \quad=$ Parameter yang diukur

$\mathrm{X}_{1} \quad=$ Pengembangan Karir

$\mathrm{X}_{2} \quad=$ Manajemen Konflik

e $\quad=$ Error / variabel pengganggu

4. Uji Hipotesis

a. Pada penelitian ini, uji F dipakai untuk mengetahui tingkat signifikansi pengaruh variabel-variabel independen secara bersama (simultan) terhadap variabel dependen (Ghozali, 2006:84). Hipotesis yang digunakan dalam pengujian ini adalah:

1. Apabila signifikansi $\mathrm{F}>0,05$, maka variabel-variabel bebas yaitu pengembangan karir dan manajemen konflik tidak berpengaruh secara signifikan secara bersama-sama terhadap variabel terikatnya yaitu kinerja pegawai.

2. Apabila signifikansi $\mathrm{F}<0,05$, maka variabel-variabel bebas yaitu pengembangan karir dan manajemen konflik berpengaruh secara signifikan secara bersama-sama terhadap variabel terikatnya yaitu kinerja pegawai.

b. Uji T dipakai menguji signifikansi hubungan antara variabel X dan Y, apakah variabel X1 dan X2 memang berpengaruh terhadap variabel Y secara terpisah atau parsial (Ghozali, 2006:84). Hipotesis yang dipakai pada pengujian ini yaitu: 
Vol. 6, No.2, Mei 2020, 167-176

1. Apabila signifikansi $t>0,05$, maka variabel-variabel bebas (pengembangan karir dan manajemen konflik) tidak berpengaruh signifikan terhadap variabel terikat (kinerja pegawai).

2. Apabila signifikansi $t<0,05$, maka variabel-variabel bebas (pengembangan karir dan manajemen konflik) berpengaruh signifikan terhadap variabel terikat (kinerja pegawai).

\section{HASIL DAN PEMBAHASAN}

Analisis Regresi Linear Berganda

Tabel 2. Hasil Uji Analisis Regresi Linear Berganda

\begin{tabular}{|c|c|c|c|c|c|}
\hline \multirow[b]{2}{*}{ Model } & \multicolumn{2}{|c|}{$\begin{array}{l}\text { Unstandardized } \\
\text { Coefficients }\end{array}$} & \begin{tabular}{|l} 
Standardized \\
Coefficients
\end{tabular} & \multirow[b]{2}{*}{$\mathbf{T}$} & \multirow[b]{2}{*}{ Sig. } \\
\hline & B & Std. Error & Beta & & \\
\hline (Constant) & 1.685 & 0.252 & & 6.681 & 0.000 \\
\hline $1 \begin{array}{l}\text { X1(Pengembangan } \\
\text { karir) }\end{array}$ & 0.317 & 0.065 & 0.402 & 4.845 & 0.000 \\
\hline $\begin{array}{l}\text { X2(Manajemen } \\
\text { konflik) }\end{array}$ & 0.463 & 0.057 & 0.674 & 8.116 & 0.000 \\
\hline $\begin{array}{ll}\text { Multi } R & = \\
\text { R Square }\left(R^{2}\right) & = \\
\text { Adjusted R Square } & =\end{array}$ & $\begin{array}{l}0,894^{a} \\
0,798 \\
0,786\end{array}$ & F- hitu & $=$ & $\begin{array}{l}65.358 \\
0.000^{a}\end{array}$ & \\
\hline
\end{tabular}

Sumber: Data diolah 2018, (Lampiran)

Berdasarkan nilai dari Tabel 2 di atas, maka persamaan regresi linear berganda dapat dirumuskan sebagai berikut:

$$
Y=1.685+0,317 X_{1}+0,463 X_{2}
$$

Persamaan di atas menunjukkan, variabel independen yang dianalisis berupa variabel pengembangan karir $\left(\mathrm{X}_{1}\right)$ dan manajemen konflik $\left(\mathrm{X}_{2}\right)$ memberikan pengaruh pada variabel independen kinerja pegawai (Y). Model analisis regresi kinerja pegawai BPJS Kesehatan Cabang Sisingamangaraja Palu dapat dilihat sebagai berikut.

a. Untuk nilai konstanta sebesar 1.685 berarti kinerja pegawai BPJS Kesehatan Cabang Sisingamangaraja Palu sebelum adanya variabel independen (pengembangan karir dan manajemen konflik) adalah sebesar 1.685 .

b. Pengembangan karir $\left(X_{1}\right)$ dengan nilai koefisien regresi 0,402 atau $40,2 \%$ ini berarti terjadi pengaruh positif antara pengembangan karir $\left(\mathrm{X}_{1}\right)$ dan kinerja pegawai $(\mathrm{Y})$ pada BPJS Kesehatan Cabang Sisingamangaraja Palu.

c. Manajemen konflik $\left(\mathrm{X}_{2}\right)$ dengan nilai koefisien 0.674 atau $67,4 \%$ ini berarti bahwa terjadi pengaruh positif antara manajemen konflik $\left(\mathrm{X}_{2}\right)$ Lebih baik maka akan meningkatkan kinerja pegawai (Y) pada BPJS Kesehatan Cabang Sisingamangaraja Palu.

Pengujian Hipotesis

\section{Uji F}

Berdasarkan Tabel 2 terlihat hasil perhitungan diperoleh $F_{\text {hitung }} 65,358$ pada taraf nyata $\alpha=0,05$ dan nilai signifikan $F=0,000<0,05$. Kesimpulannya adalah bahwa variabel independen yakni pengembangan karir $\left(\mathrm{X}_{1}\right)$ dan manajemen konflik $\left(\mathrm{X}_{2}\right)$ secara simultan berpengaruh signifikan terhadap variabel dependen yaitu kinerja pegawai (Y). Pada BPJS Kesehatan Cabang Sisingamangaraja Palu. Berdasarkan hasil tersebut dapat disimpulkan bahwa hipotesis pertama terbukti ( $\mathrm{H}_{0}$ ditolak dan $\mathrm{H}_{\mathrm{a}}$ diterima).

Uji T

1. Pengembangan Karir $\left(\mathrm{X}_{1}\right)$ 
Berdasarkan tabel 5.9, hasil pengujian dengan SPSS diperoleh angka signifikansi sebesar 0,000. Angka $0,000<0,05$ oleh karena itu, hipotesis diterima. Hal ini berarti variabel $\mathrm{X}_{1}$ (pengembangan karir) berpengaruh signifikan terhadap variabel $\mathrm{Y}$ (kinerja pegawai). Berdasarkan hasil tersebut, dapat disimpulkan bahwa hipotesis kedua terbukti ( $\mathrm{H}_{0}$ ditolak dan $\mathrm{H}_{\mathrm{a}}$ diterima).

2. Manajemen Konflik $\left(\mathrm{X}_{2}\right)$

Berdasarkan tabel 5.9, hasil pengujian dengan SPSS diperoleh angka signifikansi sebesar 0,000. Angka $0,000<0,05$ oleh karena itu hipotesis diterima. Hal ini berarti variabel $\mathrm{X}_{2}$ (Manajemen Konflik) berpengaruh signifikan terhadap variabel Y (Kinerja Pegawai). Berdasarkan hasil tersebut dapat disimpulkan bahwa hipotesis ketiga terbukti $\left(\mathrm{H}_{0}\right.$ ditolak dan $\mathrm{H}_{\mathrm{a}}$ diterima).

\section{KESIMPULAN DAN SARAN}

Kesimpulan

1. Pengembangan karir dan manajemen konflik secara serempak berpengaruh positif dan signifikan terhadap kinerja pegawai BPJS Kesehatan Cabang Palu.

2. Pengembangan karir secara parsial berpengaruh positif dan signifikan terhadap kinerja pegawai BPJS Kesehatan Cabang Palu.

3. Manajemen konflik secara parsial berpengaruh positif dan signifikan terhadap kinerja pegawai BPJS Kesehatan Cabang Palu.

Saran

1. Meningkatkan peran pemimpin atau manajemen atas untuk dapat meningkatkan kinerja pegawai. Khususnya dalam proses pengembangan karir pegawai, perusahaan harus lebih memperlakukan pegawai secara adil dalam penempatan posisi/jabatan sesuai kemampuan dan keterampilan pegawai dalam melaksanakan pekerjaan sehingga eksistensi dan kemajuan baik dari pihak pegawai maupun perusahaan akan semakin berkembang.

2. Penerapan Manajemen konflik di dalam perusahaan harus dipertahankan, dalam hal ini pada proses pengakomodasian didalam perusahaan. Sehingga ke depannya pemimpin atau manajamen atas, dapat mengatasi masalah-masalah yang timbul, baik itu dari pihak organisasi maupun pihak pegawai sehingga apa yang menjadi harapan dan tujuan perusahaan di kemudian hari akan terwujudkan.

3. Memperhatikan proses kinerja pegawai, bila perlu diadakan pengarahan kepada para pegawai untuk dapat meningkatkan proses kinerja mereka terutama dalam hal jumlah dan kualitas pekerjaan.

\section{REFERENSI}

Bianca Audra, Susihono Wahyu. 2012. Pengaruh Iklim Organisasi dan Pengembangan Karir Terhadap Kepuasan Kerja Karyawan Spektrum Industri. Jurnal STIE Semarang, Vol 10, No 2, Hal 174.

Fransisca, Mahardiana, Kornelius. 2019. Pengaruh Pelatihan dan Lingkungan Kerja Terhadap Kinerja Pegawai Negeri Sipil Dinas Koperasi UMKM Provinsi Sulawesi Tengah. Jurnal Ilmu Manajemen Universitas Tadulako, Vol 5, No 1.

Ghozali, Imam, 2013. Aplikasi Analisis Multivariate Program dengan program SPSS. Edisi ke tuju. BP Universitas Diponegoro: Semarang.

Handoko, T. Hani, 2001. Manajemen Personalia dan Sumber Daya Manusia, Edisi 2 Cetakan 15, BPFE: Yogyakarta.

Hasibuan, Malayu S.P., 2002. Manajemen Sumber Daya Manusia, Edisi Revisi Cetakan ke 5, Bumi Aksara: Jakarta. 
Heridiansyah, 2014. Manajemen Konflik Dalam Sebuah Organisasi. Jurnal STIE Semarang, Vol 6, No 1, Hal 30-31.

Kahesaran F.H, Mandey S.L, Mekel P.A. 2014. Pengaruh Motivasi, Penempatan Kerja, dan Pengembangan Karir Terhadap Kinerja Pegawai Pada Badan Lingkungan Hidup Privinsi Sulawesi Utara. Jurnal ISSN, Vol 2, No 4, Hal 185.

Kasegar, Regina Gledy. 2013. Pengembangan Karir dan SELF-EFFICACY Terhadap Kinerja Karyawan Pada PT. Matahari Department Store Manado Town Square. Jurnal EMBA. Vol 1, No 4, Desember 2013.

Mangkunegara. A. A. Anwar Prabu. 2013. Manajemen Sumberdaya Manusia Perusahaan.PT. Remaja Rosdakarya: Bandung.

Mawarni, Iskandarsyah Madjid. Fachrurraz Zamzi. 2012. Pengaruh Iklim Organisasi dan Pengembangan Karir Terhadap Kinerja Pegawai Dinas Sosial Aceh. Jurnal Manajemen Pascasarjana Universitas Syiah Kuala. ISSN: 2302-0199. Vol 2, No 1, November 2012.

Muazzan Alamsyah, Seno Andri. 2016. Pengaruh Pengembangan Karir dan Komitmen Organisasi Terhadap Kinerja Karyawan Pada PT. Indah Logistik Cargo Pekanbaru. Jom Fisip. Vol 3, No 2, Oktober 2016.

Nugroho, AD, Kunartinah. 2012. Analisis Pengaruh Kompetensi dan pengembangan karir terhadap kinerja dengan mediasi motivasi kerja. Jurnal Bisnis dan Ekonomi . Vol 19, No 2, Hal 156.

Panggabean, Mutiara Sibarani. 2002. Manajemen Sumber Daya Manusia. Ghalia Indonesia: Bojongkerta, Ciawi - Bogor Selatan.

Rivai, V. dan E.J. Sagala, 2009, Manajemen Sumber Daya Manusia Untuk Perusahaan: Dari Teori ke Praktik2. Edisi 2, PT. Raja Grafindo Perkasa: Jakarta.

Rozalina, 2013. Pengaruh Gaya Kepemimpinan dan Manajemen Konflik Terhadap Kinerja Karyawan PT. Sinar Sosro Kantor Penjualan Wilayah (KPW) Jawa Timur. Jurnal Eksekutif Vol 10, No. 1 Juni 2013.

Sadarmayani, 2014. Manajemen Sumberdaya Manusia: Reformasi Birokrasi dan Manajemen Pegawai Negeri Sipil, PT. Refika Aditama: Bandung.

Sahabudin \& Dian. 2018. Wawancara Manajemen Konflik. Tanggal 08 Juni, Palu.

Siagian, 2002. Manajemen Sumber Daya Manusia. PT. Bumi Aksara: Jakarta.

-------. 2006. Manajemen Sumber Daya Manusia. PT. Bumi Aksara: Jakarta.

Sugiyono, 2014. Metodologi Penelitian Bisnis (Pendekatan Kuantitatif, Kualitatif, dan R\&D), Alfabeta: Bandung.

Suyati, Vika Erika. 2011. Analisis Pengaruh Manajemen Konflik dan Stres Kerja Terhadap Kinerja Karyawan Pada PT. General Adjuster Indonesia. Jurnal Manajemen Konflik, Stres Kerja, Kinerja Karyawan, Regresi. Vol 1, No 1, Hal 2-3.

Syafi'I saat, Murniati, Nasir Usman. 2015. Manajemen Konflik Pada Organisasi Sekolah dalam Meningkatkan Kinerja Guru Min Bener Kelipah Kecamatan Bener Kelipah Kabupaten Bener Meriah. Jurnal Administrasi Pendidikan, ISSN 2302-0156, Vol 3, No 4, November 2015. 
Vosta 2018. Wawancara Kinerja Pegawai. Tanggal 07 Juni, Palu.

Wawancara Pengembangan Karir. Tanggal 07 Juni, Palu.

Wahyudi. 2015. Manajemen Konflik Dalam Organisasi. Cetakan kelima. Alfabeta: Bandung.

Wirawan, 2010. Konflik Dan Manajemen Konflik. Teori, Aplikasi, dan Penelitian. Salemba Empat: Jakarta.

Winardi, 2007. Manajemen Konflik, konflik Perubahan dan Pengembangan. Mandar Maju: Bandung. 